\title{
Public Service Performance and Public Trust in Government An Indonesian Case Study
}

\author{
Gita Susanti \\ Faculty of Social and Political Sciences \\ University of Hasanuddin \\ Makassar, Indonesia \\ gitasusanti65@gmail.com \\ St. Halwatiah \\ Faculty of Social and Political Sciences \\ University of Hasanuddin \\ Makassar, Indonesia \\ Novayanti Sopia Rukmana \\ Faculty of Social and Political Sciences \\ STISIP Muhammadiyah Sinjai \\ Sinjai, Indonesia
}

\author{
Andi Ahmad Yani \\ Faculty of Social and Political Sciences \\ University of Hasanuddin \\ Makassar, Indonesia \\ Andi Rahmat Hidayat \\ Faculty of Social and Political Sciences \\ University of West Sulawesi \\ Majene, Indonesia \\ Suherman Ahmad \\ Department of Administrative Science \\ University of Hasanuddin \\ Makassar, Indonesia
}

\begin{abstract}
This study aims to determine public performance and public trust to government over education, health, population and security. This research used a quantitative approach, and the data in this research were collected by Asian Barometer Survey conducted in 33 provinces in Indonesia. Data collection by Asian Barometer Survey used questionnaire instrument with the sample of 1.500 people but who successfully interviewed as many as $\mathbf{1 . 2 2 6}$ people. The results of this study indicated that there is influence between public performance and public confidence in government in Indonesia.
\end{abstract}

Keywords: public service; performance; public trust; government

\section{INTRODUCTION}

Government and people are inseparable elements in political and public administration discourse. The former can be recognized as an institution that runs bureaucracy and provides public services, and the latter is described as target group of government's policy and services. This clearly shows the relations between government and people, and they need one another. In this context, trust has a fundamental role to build reciprocal relation, where trust is a concept that is now well developed in good governance discourse [1] [2] [3 [4]. Public trust on government helps fulfill political accountability and discretion that are required to form more flexible government, encouraging people to recognize government's authority [5]. Moreover, trust can be explained as basis for the creation of all human relation and institutional interaction [6] [7].

Corresponding authors: Gita Susanti
One of the main types of trust is political trust. This trust is illustrated when people value their government and its institution, referring to perspective of trust and not trust and, satisfaction and dissatisfaction with the public toward alternative government policies [8]. This is in line with survey result conducted by Asian Barometer Survey about public trust on government in several countries in East Asia with varied political system.

Countries that were taken as sample in Asian Barometer Survey (Wave III) 2010-2011can be groped based on government system they have. There are three models of government system identified, and the first is liberal democracy where Japan, South Korea and Taiwan belong to this system. Indonesia, Mongolia, Filipina and Thailand refers to electoral democracy, and the third system of government is autocracy which is Singapore and Malaysia.

Liberal democracy that is applied in Japan, South Korea and Taiwan has shown low level of public trust on government institution. This level of trust toward national government has been measured over a period of ten years, and the percentage of level of trust in these three countries ranges from an average of 18 per cent in Japan, 21 per cent in South Korea and 36 per cent in Taiwan. While the level of public confidence in parliamentary institutions shows a lower percentage of 13 per cent in Japan, 11 per cent in South Korea and 19 per cent in Taiwan [9].

Electoral democracy that is implemented in Indonesia, Mongolia, Filipina and Thailand indicates that public confidence on government is 61 per cent in Indonesia, 50 per cent in Mongolia, 44 per cent in the Philippines and 60 per cent in Thailand. Then the level of public trust in its parliamentary institutions shows a percentage of 55 percent in 
Indonesia, 48 percent in Mongolia, 42 per cent in the Philippines and 54 per cent in Thailand [9].

Autocracy applied in Malaysia and Singapore shows very high level of trust on government institution, with an average of 73 per cent in Malaysia and 88 per cent in Singapore. Meanwhile, for its parliamentary institutions, the trust rate is 67 per cent in Malaysia and 84 per cent in Singapore. From the mapping result, it was found that the level of public confidence in government in a country with a liberal democratic system is lower than that of the state with electoral democracy and electoral system. This suggests that a governance system such as democracy where civil liberties and political rights are broader does not necessarily lead to high level of public trust, but the quality of government itself plays a major role in generating public confidence. Therefore, public trust on government is not determined by the system of government [9].

Based on the results of a study that identifies and examines factors that contribute to the decline of public confidence on government, it indicates that the economic situation, administrative performance of government institutions and its programs, ignorance and dishonesty affect public trust on government. Then social capital, political scandals, and media intervention can also lead to lower levels of trust in government [10] [11] [12] [13] [14].

In addition, the factors that predominantly influence the level of public trust are the performance of government agencies and compliance, as well as the participation of communities that impact public trust on government [15]. In this sense, the focus of this study is public trust on the performance of public services in education, health, security and population sectors in Indonesia by using data (survey results) from Asian Barometer Survey (Wave III) 2010-2011.

\section{RESEARCH METHOD}

This research uses quantitative approach, using data from Asian Barometer Survey (Wave III) that was published two years after the survey had been conducted. Asian Barometer Survey has surveyed 33 provinces in Indonesia on 9-23 May 2011. Then the result of this survey was taken as primary data in this research. Thus, the study conducted following data from the Asian Barometer Survey (Wave III). The total population used in the Asian Barometer Survey is all Indonesians who are mature or married and are eligible to exercise their voting right during the election. The total population is $171,068,667$ people based on data on the number of voters in the 2009 elections.

The sample in this study was taken using the following formula:

$$
\pm Z^{*} \sqrt{\frac{p(1-p)}{n}}
$$

With $95 \%$ confidence level and $\pm 2.5 \%$ margin error, the specified number of sample is 1,500 people. The Asian Barometer Survey successfully interviewed 1,226 people or
$79 \%$ of the total expected sample. This research uses multi stage random sampling in selecting samples. Asian barometer survey uses 5 stages in choosing respondents, namely: Stage 1, Indonesia is divided into 33 Provinces and village list used as primary sampling unit. Based on the proportion of population in each province, city and village, we took 155 villages which were randomly selected-proportional sample. Stage 2, Selection of the smallest environmental unit is the selection of environmental units on the smallest unit at the village level. The smallest environmental level in the village is "RT" (Household) level which was registered and selected using a random number table. Stage 3, Household Election chooses two households (RT) using household random number (RT). Stage 4, Selection of respondents, in each elected household (RT), we selected female or male respondents in the household using a kish grid. Stage 5 for respondent substitute, if the respondent selected by using the kish grid cannot be interviewed because the correspondent is not in place after two visits or in the condition of refusing to be interviewed, then selected respondent replacement starts with stage 3 and stage 4.

Type and source of data in this study used primary data from the survey results produced by Asian Barometer Survey (ABS) Wave III. This data collection was conducted on 9-23 May 2011. This study used the Product Moment Correlation method in analyzing data to determine whether or not there is relationship of free variable or bound variable with the research hypothesis as follows:

H0 : The performance of public services in education, health, security and population sectors does not have effect on public trust on government performance.

H1 : The performance of public services in education, health, security and population sectors has a positive influence on public confidence in government performance.

Government performance is the quality of government services in the education, health, security and demographic administration services questioned in the Asian Barometer Survey (Wave III) study. Questions in the Asian Barometer Survey questionnaire are as follows variable public services. How easy or difficult is to get the following services? Or have you ever tried to get this service from the government? identity documents (such as birth certificates or passports), a place in public elementary school for children, treatment at a nearby clinic, help from the police when you need them. Public confidence in the government is derived from questions asked in the Asian Barometer Survey (Wave III) study. Questions in the questionnaire were as follows variable public trust. For each, please tell me how much trust do you have in national government, employees, the police, and local Government. 


\section{RESULT AND DISCUSSION}

The following is results of the data on the correlation between variables through the F-test, which includes the performance of government in the education sector to public trust, government performance on the health sector to public trust, government performance on the security sector to public trust and government performance on the population sector to public trust:

\begin{tabular}{|c|l|c|c|c|}
\hline No. & $\begin{array}{c}|c| \\
\text { The } \\
\text { correlated } \\
\text { variable }\end{array}$ & $\mathbf{F}_{\text {count }}$ & $\mathbf{F}_{\text {table }}$ & Description \\
\hline 1. & $\begin{array}{l}\text { Education } \\
\text { on Public } \\
\text { Trust }\end{array}$ & 39,909 & 3,850 & Significant \\
\hline 2. & $\begin{array}{l}\text { Health on } \\
\text { Public Trust }\end{array}$ & 34,082 & 3,850 & Significant \\
\hline 3. & $\begin{array}{l}\text { Security on } \\
\text { Public Trust }\end{array}$ & 38,737 & 3,850 & Significant \\
\hline 4. & $\begin{array}{l}\text { Population } \\
\text { on Public } \\
\text { Trust }\end{array}$ & 13,238 & 3,850 & Significant \\
\hline
\end{tabular}

Based on table 1 above, it is found that there is a significant influence between the performance of public service government in education sector to public trust, indicated by $F_{\text {count }}(39,909)>F_{\text {table }}(3,850)$. One of the government policies in education that is still ongoing is the School Operational Assistance Program (BOS) [16]. This program is used to meet student needs and to improve teacher's competence. With this BOS funds, it is hoped that no children will be dropped out of school and can continue and complete their education for at least 9 years as programmed by the government. From the above table, it also shows a significant influence between services in the field of Education to public confidence.

The performance of government public services in the health sector has a significant influence on public trust. Based on table 1 above, then $F_{\text {count }}(34,082)>F_{\text {table }}(3,850)$. So, it is found that there is a significant influence between health on public trust. This is based on the existence of a national health insurance system obtained by the community, especially health insurance for the poor. The National Health System (SKN) is a form and mode of health development that integrates the efforts of the Indonesian nation to ensure the achievement of health development goals in the framework of realizing the people's welfare as defined in the 1945 Constitution. The National Health System as one of government programs was designed to overcome various problems, and in its operations, it went well.

Some of study results related to the influence of public confidence on the performance of public service in the health sector is the result of a survey in Scania, Southern Sweden with random sample of 47,621 persons aged 18-80 years during the autumn (September-December) in 2004. It shows how people trusted on the government as a public service provider [17]. The findings of the survey also indicate that the community always believed in the government without considering the capacity of public service providers in providing services to the community. This is due to their belief that the government will always fulfill the needs of the community in providing public services.

Effect of government public service performance on the security sector on public trust shows a significant influence. This refers to the results of the data processed in table 1 above, that is $\mathrm{F}_{\text {count }}(38.737)>\mathrm{F}_{\text {table }}(3.850)$. It is found that there is a significant influence between the performance of government public services on the security sector to public trust. The performance of public service of the government on the security sector is one of them seen from the implementation of Law Number 15 Year 2003 on Stipulation of Government Regulation in Combating Terrorism. Once the rule is implemented, it gradually reduces the case of terrorism in the last period. Public confidence in government performance is influenced by the quality of government performance itself, when government performance is bad, it can affect public confidence. For instance, attacks on the World Trade Center (WTC) and the Pentagon on 11 September 2001 had caused significant decrease of people's confidence in the performance of the government [18].

The performance of government public services in the population sector significantly affects public trust. Based on table 1 above, it is then $F_{\text {count }}(13.238)>F_{\text {table }}(3.850)$. It is then obtained the result that there is a significant influence between the performance of government public service on the population sector to public trust. This is one of them influenced by the Decree of Minister of Law and Human Rights Number: M.02.IZ.03.10 Year 2006 [19], concerning implementation of Biometric Based Integrated Photo System in Travel Letter Republic of Indonesia. This is implemented with the aim of facilitating the passport service which at the same time put forward the security aspect. The policy received a positive response from the community because it is considered to facilitate the service of passport management for the community.

\section{CONCLUSION}

Public demand for quality service urges the government to continue to improve itself. trust in government is strongly connected with public support to government, while government has high integrity in public service, then it will also be followed by enhanced public trust to government. The level of public confidence in the government will be greatly influenced by the government's ability to be ruled out, to protect the community, to be responsive, to be just and to improve the welfare of the people. The services provided in the education, security, demographics, health sectors so far received good response from the public. Some policies issued by the government are able to overcome some of the problems that occur. This means that public trust has a good effect on the government's performance in terms of public services. 


\section{ACKNOWLEDGMENT}

We thank to Department of Administrative Science, Hasanuddin University, Muh. Irvan Nur Iva, and Paramita Mayadewi Maraly who have provided assistance during the research process. Data analyzed in this article were collected by the Asian Barometer Project (2011), which was co-directed by Professors $\mathrm{Fu} \mathrm{Hu}$ and Yun-han $\mathrm{Chu}$ and received major funding support from Taiwan's Ministry of Education, Academia Sinica and National Taiwan University. The Asian Barometer Project Office (www.asianbarometer.org) is solely responsible for the data distribution. The author appreciates the assistance in providing data by the institutes and individuals afore mentioned. The views expressed herein are the author's own.

\section{REFERENCES}

[1] K. S Cook, R. Hardin,, and M. Levi, Cooperation without trust. New York: Russell Sage.2005.

[2] F. Fukuyama, Trust: The Social Virtues and The Creation of Prosperity. New York: Free Press.1995.

[3] R. Putnam, The Prosperous Community: Social Capital and Public Life. The American Prospect.1993, pp. 4-13.

[4] E. Ostrom and J. Walker. Trust and Reciprocity: Interdisciplinary lesson from experimental research. New York: Russel Sage Foundation. 2003.

[5] K.P.Ruscio. Trust in the Administrative State, Public Administration Review 57:454-58. 1997.

[6] F. Tonkiss, A. Passey, N. Fenton and L.C. Hems. Trust and Civil Society. London: Macmillan, 2000.

[7] B.A.Mistzal. Trust in Modern Societies: The Search for the Bases of Social Order. Cambridge: Polity Press, 1996.

[8] A.H. Miller and O. Listhaug. "Political Parties and Confidence in Government: A Comparison of Norway, Sweden and The United States," British Journal of Political Science 20, 1990, pp. 357-386.
[9] C.M. park \& J.H Bae, "Source of Public Trust in Governance: East Asian Evidence", on Workshop Trust in Public Administration in Korea, 2012.

[10] J. Nye "Introduction: The Decline of Confidence in Government," in Why People Don't Trust Government? Cambridge: Harvard University Press. 1997

[11] C.W.Thomas. Maintaining and restoring public trust in government agencies and their employees. Administration \& Society, 30, 166193. 1998 .

[12] R. Putnam. Bowling Alone: The Collapse and Revival of American Community. New York: Simon and Schuster. 2000.

[13] W.Mishler and R. Rose. What Are the Origins of Political Trust: Testing Institutional and Cultural Theories in Post-Communist Societies, Comparative Political Studies 34,1:30-62. 2001.

[14] E. Vigoda. Stress-Related Aftermaths to Workplace Politics: An Empirical Assessment of The Relationship Among Organizational Politics, Job Stress, Burnout, and Aggressive Behavior. Journal of Organizational Behavior, 23, hal. 571-91.2002.

[15] S. O. Choi and S. Kim. An Exploratory Model of Antecedents and Consequences of Public Trust in Government. Journal. Korea: Seoul National University.2012.

[16] Asian Barometer Survey Data

[17] M. Mohseni, M. Linstorm, "Social Capital, Trust in the Health-care System and Self-rated Health: The Role of Access to Health Care in a Population", Social Science \& Medicine 64, 2007, pp. 1373-1383.

[18] V. A. Chanley, Trust in Government in the Aftermath of $9 / 11=$ Determine and Consequences. Political Psychology, Vol 23, No. 3, 2002.

[19] Decree of the Minister of Law and Human Rights Number: M.02.IZ.03.10 Year 2006 concerning Implementation of Biometric Based Integrated Photo System in Travel Letter of the Republic of Indonesia 